\title{
Inhibition of Horseradish Peroxidase Activity by Boroxine Derivative, Dipotassium-trioxohydroxytetrafluorotriborate $\mathbf{K}_{2}\left[\mathbf{B}_{3} \mathbf{O}_{3} \mathbf{F}_{4} \mathbf{O H}\right]$
}

\author{
Jelena Ostojic, ${ }^{1}$ Safija Herenda, ${ }^{1}$ Semira Galijasevic, ${ }^{2}$ Borivoj Galic, ${ }^{1}$ and Mladen Milos ${ }^{3}$ \\ ${ }^{1}$ Faculty of Science, University of Sarajevo, Sarajevo, Bosnia and Herzegovina \\ ${ }^{2}$ School of Science and Technology, Sarajevo Medical School, Sarajevo, Bosnia and Herzegovina \\ ${ }^{3}$ Faculty of Chemistry and Technology, University of Split, Split, Croatia \\ Correspondence should be addressed to Mladen Milos; milos@ktf-split.hr
}

Received 14 November 2016; Revised 17 February 2017; Accepted 21 February 2017; Published 8 March 2017

Academic Editor: Sevgi Kolaylı

Copyright (C) 2017 Jelena Ostojic et al. This is an open access article distributed under the Creative Commons Attribution License, which permits unrestricted use, distribution, and reproduction in any medium, provided the original work is properly cited.

Recently research shows that horseradish peroxidase, HRP, when combined with other compounds, is highly reactive toward different human tumour cells and that better understanding of catalytic mechanism and inhibition HPR could lead to a new targeted cancer therapy. Thus, the inhibition of HRP activity by dipotassium-trioxohydroxytetrafluorotriborate $\mathrm{K}_{2}\left[\mathrm{~B}_{3} \mathrm{O}_{3} \mathrm{~F}_{4} \mathrm{OH}\right]$ was investigated for possible explanation of previously observed antitumour activities of this promising drug. HRP activity was studied under steady-state kinetic conditions by a spectrophotometric method. In the absence of the inhibitor values of $K_{m}=$ $0.47 \mathrm{mM}$ and $V_{\max }=0.34 \mathrm{mM} \mathrm{min}^{-1}$, respectively, were determined. The hydrogen peroxide $\mathrm{H}_{2} \mathrm{O}_{2}$ kinetic measurements show a competitive inhibition with the inhibition constant $K_{I}=2.56 \mathrm{mM}$. The activation energy $E_{a}$ values were found to be very similar for both reactions; in the absence of inhibitor activation energy was $17.7 \mathrm{~kJ} \mathrm{~mol}^{-1}$ and in the presence of inhibitor activation energy was $16.3 \mathrm{~kJ} \mathrm{~mol}^{-1}$. The values of Arrhenius constants were found to be different; $A=4.635 \mathrm{~s}^{-1}$ was measured in the absence of inhibitor while in the presence of inhibitor Arrhenius constant was $1.745 \mathrm{~s}^{-1}$ showing that $\mathrm{K}_{2}\left[\mathrm{~B}_{3} \mathrm{O}_{3} \mathrm{~F}_{4} \mathrm{OH}\right]$ initiates conformational change in the structure of the HRP and subsequently reduces its activity.

\section{Introduction}

Boroxines are the dehydration products of organoboronic acids $[1,2]$. Due to their unique electronic structures, these compounds are currently under investigation as possible therapeutics and enzyme inhibitors. The boroxine derivative, dipotassium-trioxohydroxytetrafluorotriborate $\mathrm{K}_{2}\left[\mathrm{~B}_{3} \mathrm{O}_{3} \mathrm{~F}_{4} \mathrm{OH}\right]$, has been explored as useful in a treatment of benign and malignant skin changes, such as nevus or skin cancers $[3,4]$. First published effects of its bioactivity revealed a potential for inhibition of lymphocytes proliferation and cell growth of basal cell carcinoma culture as well as certain clastogenic potential [5]. Recently it has been confirmed that selected flavonoids may inhibit damage of genetic material in human lymphocytes induced by $\mathrm{K}_{2}\left(\mathrm{~B}_{3} \mathrm{O}_{3} \mathrm{~F}_{4} \mathrm{OH}\right)$ [6]. Previous findings of antitumour activity of $\mathrm{K}_{2}\left(\mathrm{~B}_{3} \mathrm{O}_{3} \mathrm{~F}_{4} \mathrm{OH}\right)$ in vitro and in vivo on $4 \mathrm{~T} 1$ mammary carcinoma, B16F10 melanoma, and squamous cell carcinoma SCVII revealed inhibitory effects on cell proliferation in concentration of $1 \mathrm{mM}$, while concentrations less than $0.1 \mathrm{mM}$ do not significantly affect cell growth in vitro. In vivo, $\mathrm{K}_{2}\left(\mathrm{~B}_{3} \mathrm{O}_{3} \mathrm{~F}_{4} \mathrm{OH}\right)$ slows the growth of three tested tumours compared to control regardless of the route of administration (intraperitoneally, intratumour, per oral, or as an ointment) [7]. In recent studies [8-12], the kinetic parameters and inhibition mechanisms of enzymes human carbonic anhydrases and catalase in the presence of some boron-containing anions were investigated, among them $\mathrm{K}_{2}\left[\mathrm{~B}_{3} \mathrm{O}_{3} \mathrm{~F}_{4} \mathrm{OH}\right]$, too. It was hypothesized [11] that the local application of $\mathrm{K}_{2}\left[\mathrm{~B}_{3} \mathrm{O}_{3} \mathrm{~F}_{4} \mathrm{OH}\right]$-containing cream, or by its intratumour injection at level of millimolar concentrations, could significantly reduce catalase activity and increase the concentration of hydrogen peroxide $\mathrm{H}_{2} \mathrm{O}_{2}$ in cell and accordingly produce beneficial effects in tumour tissue 
alone. In other study [12] it was shown that $\mathrm{K}_{2}\left[\mathrm{~B}_{3} \mathrm{O}_{3} \mathrm{~F}_{4} \mathrm{OH}\right]$ is a potent inhibitor of some human carbonic anhydrases with a $K_{I}$ ranging from 8.0 to $93 \mu \mathrm{M}$ and it was proposed that $\mathrm{K}_{2}\left[\mathrm{~B}_{3} \mathrm{O}_{3} \mathrm{~F}_{4} \mathrm{OH}\right]$ binds to the $\mathrm{Zn}$ (II) from active site of enzyme carbonic anhydrase, coordinating to the metal ion monodentately through its boron-OH functionality.

$\mathrm{H}_{2} \mathrm{O}_{2}$ has many roles in biological systems. One of the major deleterious roles is its involvement in an oxidative damage. During the inflammatory processes, $\mathrm{H}_{2} \mathrm{O}_{2}$ is produced in large amounts due to activation of macrophages, eosinophils, and neutrophils. In this step, with the help of several enzyme systems such as oxidases or peroxidases free radicals are produced, mainly superoxide radical $\left(\mathrm{O}_{2}{ }^{--}\right)$that consequently is involved in many reactions causing oxidative damage. $\mathrm{H}_{2} \mathrm{O}_{2}$ and malfunction of enzymes catalase and different peroxidases play a crucial role in the pathologies of many diseases. Conversely, $\mathrm{H}_{2} \mathrm{O}_{2}$ is necessary and acts as a second messenger in signal-transduction pathways. Understanding the specific involvement of different inhibitors and their relations between function and enzyme structure may help to design specific inhibitors and prevent diseases in humans, animals, and plants [13]. The family of heme peroxidases as well as HRP catalyse the $\mathrm{H}_{2} \mathrm{O}_{2}$-dependent oxidation of a wide variety of different substrates [14]. HRP was used for the investigation of inhibitor activity of anti-inflammatory drugs [15]. In other studies it has been found that better understanding the role of HRP and other peroxidases in this process could lead to a new targeted cancer therapy [16-18].

Generally, the ground state (secreted) form of the enzyme, HRP-Fe(III), reacts in a rapid manner with $\mathrm{H}_{2} \mathrm{O}_{2}$ to form Compound I, two-e ${ }^{-}$oxidized intermediate possessing, a $\mathrm{Fe}(\mathrm{IV})=\mathrm{O}$ group, and a resonance-stabilized porphyrin $\pi$ cation radical. This redox intermediate has a reduction potential of ca. $+1 \mathrm{~V}$. Alternatively, Compound I may oxidize multiple substrates through two sequential one $\mathrm{e}^{-}$steps forming Compound II which retains the oxyferryl group but not porphyrin cation radical and HRP-Fe(III), respectively. The conversion of Compound II to HRP-Fe(III) is the rate limiting step of the catalytic cycle of peroxidases. Reaction of excess hydrogen peroxide with the resting state enzyme gives compound III which is the dead end of catalytic process.

Scheme I. Classic catalytic mechanism of HRP is as follows:

$$
\begin{gathered}
\text { HRP-Fe (III) }+\mathrm{H}_{2} \mathrm{O}_{2} \longrightarrow \\
\text { Compound I }+\mathrm{H}_{2} \mathrm{O} \\
\text { Compund I }+\mathrm{AH}_{2} \longleftrightarrow \\
\text { Compound II }+\mathrm{AH}^{\bullet} \\
\text { Compound II }+\mathrm{AH}_{2} \longleftrightarrow \\
\text { HRP-Fe (III) }+\mathrm{AH}^{\bullet}+\mathrm{H}_{2} \mathrm{O}
\end{gathered}
$$

In this mechanism, $\mathrm{AH}_{2}$ and $\mathrm{AH}^{\bullet}$ are the electron donor substrate and the radical product of one-electron oxidation step, respectively. Electron donor substrate can be a number of inorganic anions, aromatic, and amine compounds.
Since HRP is considered to be as good model for the investigations of kinetic mechanisms and parameters of different enzyme inhibitors, in this paper, we report a study of inhibition impact of $\mathrm{K}_{2}\left[\mathrm{~B}_{3} \mathrm{O}_{3} \mathrm{~F}_{4} \mathrm{OH}\right]$ on its activity. This research could help us to better understand peroxidase enzymes activity in general but also the inhibitor properties of $\mathrm{K}_{2}\left[\mathrm{~B}_{3} \mathrm{O}_{3} \mathrm{~F}_{4} \mathrm{OH}\right]$ as a new and promising drug.

\section{Materials and Methods}

2.1. Chemicals. The horseradish peroxidase (EC 1.11.1.7), Guaiacol, and hydrogen peroxide solution (30\%) were purchased from Sigma-Aldrich (Buchs, Switzerland) and $\mathrm{K}_{2} \mathrm{HPO}_{4}$ and $\mathrm{KH}_{2} \mathrm{PO}_{4}$ from Fisher Chemical (Wien, Austria). $\mathrm{K}_{2}\left[\mathrm{~B}_{3} \mathrm{O}_{3} \mathrm{~F}_{4} \mathrm{OH}\right]$ is a boron inorganic derivative prepared by reacting potassium hydrofluoride $\left(\mathrm{KHF}_{2}\right)$ with boric acid working in molar ratios of $2: 3$ at room temperature, as reported in the literature [19]. All other compounds used in this study were commercially available as highest purity reagents.

2.2. Assay of HRP Activity. The HRP activity assay was determined by the measurement of Guaiacol peroxidation as described by Chance and Maehly [20]. Guaiacol is oxidized by HRP and the end product, tetraguaiacol (formed from polymerization of the radical product) and is intensely coloured, which makes it very simple to detect [21]. The initial rate of HRP catalytic reaction to oxidize Guaiacol was measured spectrophotometrically (Multiskan GO Microplate spectrophotometer, Thermo Fisher Scientific, USA) by following the increase of absorbance at $470 \mathrm{~nm}$ of the reaction mixtures within the first few minutes. The $\mathrm{H}_{2} \mathrm{O}_{2}$ kinetic measurements were performed at fixed concentration of Guaiacol $(1.33 \mathrm{mM})$ and $\mathrm{H}_{2} \mathrm{O}_{2}$ concentration varied. The reaction mixture (total volume, $300 \mu \mathrm{L}$ ) consisted of phosphate buffer, pH $6.0(100 \mathrm{mM}), 25 \mu \mathrm{L}$ of enzyme solution $\left(e_{0}=0.45 \mathrm{nM}\right.$, assuming the molecular weight of HRP as $44 \mathrm{kDa}), 25 \mu \mathrm{L}$ of Guaiacol, and the proper volume of $\mathrm{H}_{2} \mathrm{O}_{2}$ to make the above-mentioned concentrations. The reaction mixture also consisted of different amount of $\mathrm{K}_{2}\left[\mathrm{~B}_{3} \mathrm{O}_{3} \mathrm{~F}_{4} \mathrm{OH}\right]$ for different series of measurement. In very experiment, inhibitor was then preincubated with enzyme for 5 minutes before each measurement. The reaction was initiated by the addition of $\mathrm{H}_{2} \mathrm{O}_{2}$.

2.3. Effect of Temperature on HRP Activity. The effect of temperature on the HRP activity was tested at four different temperatures $22,25,30$, and $37^{\circ} \mathrm{C}$ under standard conditions for the assays with constant concentrations of [Guaiacol] = $1.33 \mathrm{mM} ;\left[\mathrm{H}_{2} \mathrm{O}_{2}\right]=0.42 \mathrm{mM}$; and $\mathrm{K}_{2}\left[\mathrm{~B}_{3} \mathrm{O}_{3} \mathrm{~F}_{4} \mathrm{OH}\right]=2 \mathrm{mM}$, at $\mathrm{pH}=6$.

2.4. Effect of $\mathrm{pH}$ on HRP Activity. The $\mathrm{pH}$ effect on the HRP activity was tested under the same working conditions using range of $\mathrm{pH} 4.5-8.0$ in $0.1 \mathrm{M}$ phosphate buffers at fixed concentrations of [Guaiacol] $=1.33 \mathrm{mM}$ and $\left[\mathrm{H}_{2} \mathrm{O}_{2}\right]=0.42 \mathrm{mM}$, in the absence and in the presence of $\mathrm{K}_{2}\left[\mathrm{~B}_{3} \mathrm{O}_{3} \mathrm{~F}_{4} \mathrm{OH}\right]=2 \mathrm{mM}$. 


\section{Results and Discussion}

Guaiacol is necessary for the spectrophotometric monitoring of HRP catalysed degradation of $\mathrm{H}_{2} \mathrm{O}_{2}$ for enzymes which react with two or more substrates; the Michaelis-Menten equation is inadequate for a full kinetic analysis of such reactions. So, although there are several graphical methods for the determination of kinetic parameters for enzymatic reactions, those are often limited due their low precision and could not reliably determine the type of enzyme inhibition of investigated inhibitor. In present study, the first results for $\mathrm{K}_{2}\left[\mathrm{~B}_{3} \mathrm{O}_{3} \mathrm{~F}_{4} \mathrm{OH}\right]$ showed competitive inhibition of HRP. It was unexpected since in our previous investigations $\mathrm{K}_{2}\left[\mathrm{~B}_{3} \mathrm{O}_{3} \mathrm{~F}_{4} \mathrm{OH}\right]$ showed noncompetitive inhibition of enzymes catalase and different carbonic anhydrases [11, 12]. Therefore, we decided to carry out a detailed kinetic research by using nonlinear regression [22] and treatment of twosubstrate enzyme kinetics $[23,24]$ in purpose to compare with the results obtained with standard graphical MichaelisMenten and Lineweaver-Burk methods in treatment by single-substrate enzyme kinetic models $[25,26]$.

3.1. Determination of $K_{m}$ and $V_{\max }$. Some important features of HRP catalytic cycle with Guaiacol as reducing substrate are illustrated in Scheme I. The generation of radical species in two one-electron reduction steps can result in a complex profile of reaction products, including the end product tetraguaiacol (formed from polymerization of the radical product).

Results showed that HRP catalysis fits the MichaelisMenten kinetic model of reversible enzyme inhibition [25] in the absence and in the presence of $\mathrm{K}_{2}\left[\mathrm{~B}_{3} \mathrm{O}_{3} \mathrm{~F}_{4} \mathrm{OH}\right]$ inhibitor. The values of $V_{\max }$ and $K_{m}$ were determined by nonlinear regression [22] from Lineweaver-Burk plots [26]. In the absence of inhibitor, the nonlinear regression from the best fit of solid line (Figure 1) showed the values $V_{\max }=$ $0.34 \mathrm{mM} \mathrm{min}^{-1}$ and $K_{m}=0.47 \mathrm{mM}$. In the presence of different concentrations of $\mathrm{K}_{2}\left[\mathrm{~B}_{3} \mathrm{O}_{3} \mathrm{~F}_{4} \mathrm{OH}\right]$, the hydrogen peroxide kinetic measurements showed Lineweaver-Burk plots (Figure 2) and gave set of straight lines that intersect $y$-axis at the same point which determine unique $V_{\max }=$ $0.34 \mathrm{mM} \mathrm{min}^{-1}$. From the straight lines intersection of $x$ axis, the apparent $K_{m}^{\text {app }}$ were variable $0.47,1.35,1.76,2.92$, and $7.85 \mathrm{mM}$ with respect to concentration of $\mathrm{K}_{2}\left[\mathrm{~B}_{3} \mathrm{O}_{3} \mathrm{~F}_{4} \mathrm{OH}\right]$ inhibitor (an example of competitive inhibition is observed).

3.2. Determination of the Inhibitor Constant $K_{I}$. The Lineweaver-Burk plots (Figure 2) were used to determine the type of inhibition and evaluation of $V_{\max }$ and $K_{m}$, in correlation to concentration of inhibitors. Using single-substrate enzyme reactions and Michaelis-Menten kinetic model, the pattern recognition for these inhibitions was a simple mode for determination of $K_{I}$. There is no significant difference between the experimental values and theoretical values of nonlinear regression calculated for particular value of $K_{I}=2.4 \mathrm{mM}$ (the best fit of solid line in Figure 1).

Since the reported steady-state parameters derived from the Lineweaver-Burk plots give apparent values of Michaelis

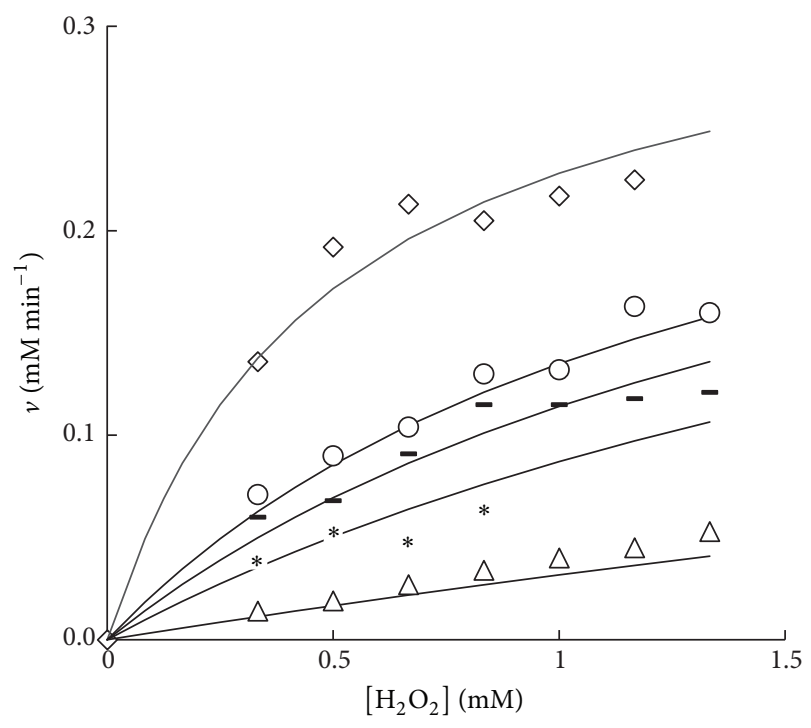

FIGURE 1: HRP kinetic measurements in the presence of different concentrations of $\mathrm{K}_{2}\left[\mathrm{~B}_{3} \mathrm{O}_{3} \mathrm{~F}_{4} \mathrm{OH}\right]$ : Michaelis-Menten plots $(\diamond)$ $0.0 \mathrm{mM},(\bigcirc) 4 \mathrm{mM},(-) 6 \mathrm{mM},(*) 10 \mathrm{mM}$, and $(\triangle) 39.6 \mathrm{mM}$; [Guaiacol] $=1.33 \mathrm{mM} ; t=22^{\circ} \mathrm{C} ; \mathrm{pH}=6$.

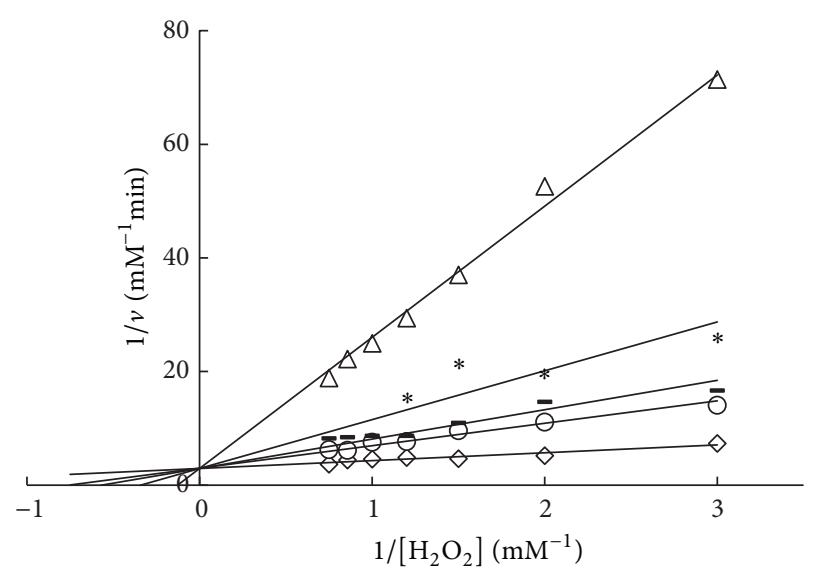

FIGURE 2: HRP kinetic measurements in the presence of different concentrations of $\mathrm{K}_{2}\left[\mathrm{~B}_{3} \mathrm{O}_{3} \mathrm{~F}_{4} \mathrm{OH}\right]$ : Lineweaver-Burk plots $(\diamond)$ $0.0 \mathrm{mM},(\bigcirc) 4 \mathrm{mM},(-) 6 \mathrm{mM},(*) 10 \mathrm{mM}$, and $(\triangle) 39.6 \mathrm{mM}$; $[$ Guaiacol $]=1.33 \mathrm{mM} ; t=22^{\circ} \mathrm{C} ; \mathrm{pH}=6$.

constant $K_{m}^{\mathrm{app}}$, which depend upon the concentration of guaiacol $(1.33 \mathrm{mM})$ and corresponding concentration of inhibitor, a model of two-substrate enzyme kinetics [23, 24] was applied for the confirmation of values determined by single-substrate model. Therefore, a simple mechanism for the action of $\mathrm{K}_{2}\left[\mathrm{~B}_{3} \mathrm{O}_{3} \mathrm{~F}_{4} \mathrm{OH}\right]$ and simplified treatment of two-substrate enzyme kinetics is proposed. In such model the inhibitor $\mathrm{K}_{2}\left[\mathrm{~B}_{3} \mathrm{O}_{3} \mathrm{~F}_{4} \mathrm{OH}\right]$ binds to both the native enzyme and Compound II with equal affinity. Further, the $\mathrm{HRP} /$ inhibitor complex is completely inactive and does not react with $\mathrm{H}_{2} \mathrm{O}_{2}$ while the Compound II/inhibitor complex is fully active with respect to Guaiacol oxidation. Essentially, Scheme I can be simplified to two reactions that affect the steady-state oxidation of Guaiacol under the conditions of the 
current experiments: (1) formation of Compound I and (2) oxidation of Guaiacol by Compound II (Scheme II).

Scheme II. Simplified two-substrate HRP kinetics is as follows:

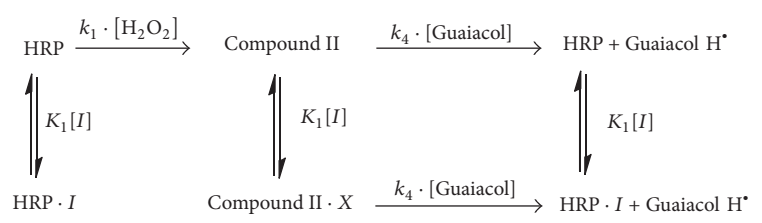

The symbol $I$ represents the inhibitor so as not to confuse it with Compound I.

The rate of Guaiacol oxidation by Compound I is about 10 times faster than oxidation by Compound II and only two enzyme species are present at significant concentrations during the steady-state experiments, native HRP and Compound II. In the absence of inhibitor and with $\mathrm{H}_{2} \mathrm{O}_{2}$ as variable substrate, $V_{\max }$ and $K_{m}$ are given by the following equations:

$$
\begin{aligned}
\frac{V_{\max }}{e_{o}} & =2 \cdot k_{4} \cdot[\text { Guaiacol }], \\
K_{m} & =\frac{k_{4} \cdot[\text { Guaiacol }]}{k_{1}} .
\end{aligned}
$$

The ratio of the maximum velocity and Michaelis constant give the most precise value for constants $k_{1}$ and $k_{4}$. Using $V_{\max }=0.34 \mathrm{mM} \mathrm{min}^{-1}, K_{m}=0.47 \mathrm{mM}$, and $e_{o}=0.45 \mathrm{nM}$, the calculated value of rate constant $k_{4}$ from (3) is $k_{4}=4.7 \times$ $10^{6} \mathrm{M}^{-1} \mathrm{~s}^{-1}$ and $k_{1}$ from (4) is $k_{1}=1.4 \times 10^{7} \mathrm{M}^{-1} \mathrm{~s}^{-1}$.

In the presence of inhibitor, the steady-state parameters are given by (3) and by equation for apparent Michaelis constant:

$$
K_{m}^{\mathrm{app}}=\frac{k_{4} \cdot[\text { Guaiacol }] \cdot\left(K_{I}+[I]\right)}{k_{1} \cdot K_{I}} .
$$

In this case, the inhibitor has no effect on the maximum velocity $V_{\max }$ and increases $K_{m}$ in a linear fashion with inhibitor concentration $[I]$, confirming an example of competitive inhibition and consistent with the data shown in Figure 2.

As previously described [27], the evaluation of $K_{I}$ from these measurements is easily done by plotting the apparent $K_{m}^{\text {app }} / K_{m}$ values as a function of inhibitor concentration $[I]$. The dependence of the initial velocity $(v)$ on substrate concentration, $[S]$, in the presence of constant inhibitor concentration, may be described by the Michaelis-Menten equation [25]

$$
v=\frac{V_{\max }[S]}{\left(K_{m}^{\mathrm{app}}+[S]\right)},
$$

where $K_{m}^{\text {app }}$ defined as

$$
K_{m}^{\mathrm{app}}=K_{m}\left(1+\frac{[I]}{K_{I}}\right)
$$

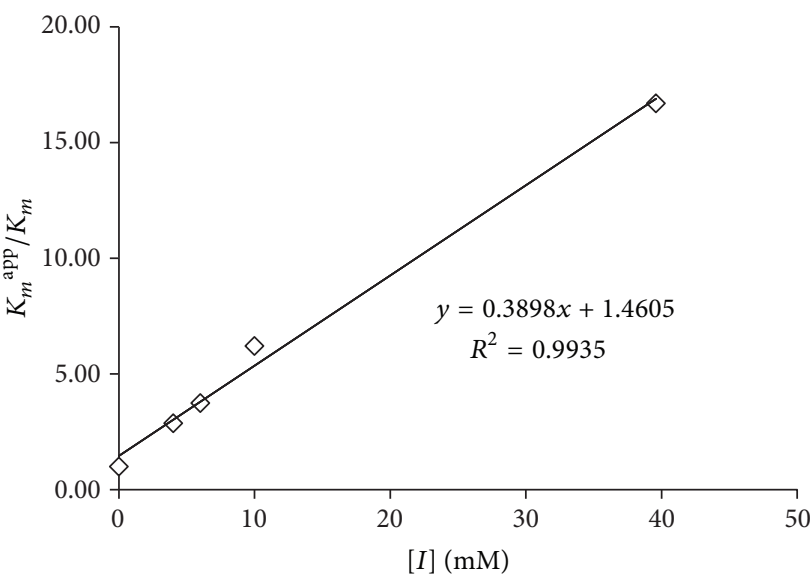

FIGURE 3: Plot of $K_{m}^{\text {app }} / K_{m}$ versus [I] describing the inhibitory effect of $\mathrm{K}_{2}\left[\mathrm{~B}_{3} \mathrm{O}_{3} \mathrm{~F}_{4} \mathrm{OH}\right]\left(K_{m}=0.47 \mathrm{mM}\right.$, slope of $K_{I}^{-1}=0.3898$ from which $\left.K_{I}=2.56 \mathrm{mM}\right)$. For details see text.

replaces $K_{m}$, the "true" Michaelis constant (obtained in the absence of the inhibitor). Equation (7) may be transformed as follows:

$$
\frac{K_{m}^{\mathrm{app}}}{K_{m}}=1+[I] K_{I}^{-1} .
$$

Therefore, in pure competitive inhibition systems, a plot $K_{m}^{\text {app }} / K_{m}$ versus $[I]$ gives a straight line of slope $K_{I}^{-1}$. In our study this plot was linear within experimental error and a weighted linear least-squares analysis gives a slope of $K_{I}^{-1}=$ 0.3898 (Figure 3) from which $K_{I}$ can be calculated to be $2.56 \mathrm{mM}$. This value is close to the value determined by pattern recognition and so confirming proposed mechanism and competitive inhibitory action of $\mathrm{K}_{2}\left[\mathrm{~B}_{3} \mathrm{O}_{3} \mathrm{~F}_{4} \mathrm{OH}\right]$.

In similar studies, HRP was used as a model for studies of cytotoxicities as well as for biologic activities of different kind of compounds [28-30]. The melamine exhibited noncompetitive inhibition of HRP with constant inhibition $K_{I}=9.5 \mathrm{mM}$ [28] which is slightly weaker than $K_{I}$ for $\mathrm{K}_{2}\left[\mathrm{~B}_{3} \mathrm{O}_{3} \mathrm{~F}_{4} \mathrm{OH}\right]$ determined in our study. In second study [29], the inhibition of intestinal peroxidase activity by nonsteroidal anti-inflammatory drugs indomethacin and acetylsalicylic acid was investigated. Indomethacin showed competitive inhibition with very strong $K_{I}=32 \mu \mathrm{M}$ and acetylsalicylic acid exhibited noncompetitive inhibition with $K_{I}=2.7 \mathrm{mM}$ which is almost equal to $K_{I}$ for $\mathrm{K}_{2}\left[\mathrm{~B}_{3} \mathrm{O}_{3} \mathrm{~F}_{4} \mathrm{OH}\right]$. Third investigation [30] showed that all investigated uracils interact hydrophobically with HRP heme group, but the measurements showed that only the thiouracil derivatives 2thiouracil and of 6-n-propyl-2-thiouracil inhibit HRP activity (noncompetitively). Uracil and 6-n-propyluracil do not affect the peroxidase activity.

3.3. Determination of Activation Energy $E_{a}$. The activities of HRP and variation of rate constants $k$ with temperature changes were examined at four different temperatures 22, 25 , 30 , and $37^{\circ} \mathrm{C}$ in the absence and presence $\mathrm{K}_{2}\left[\mathrm{~B}_{3} \mathrm{O}_{3} \mathrm{~F}_{4} \mathrm{OH}\right]$ 
TABLE 1: Arrhenius-type equation parameters for HRP catalysis in the absence and in the presence of $\mathrm{K}_{2}\left[\mathrm{~B}_{3} \mathrm{O}_{3} \mathrm{~F}_{4} \mathrm{OH}\right]$.

\begin{tabular}{lccc}
\hline Catalysis & $A\left(\mathrm{~s}^{-1}\right)$ & $E_{a}\left(\mathrm{~kJ} \mathrm{~mol}^{-1}\right)$ & $R^{2}$ \\
\hline In the absence & 4.635 & 17.7 & 0.9983 \\
In the presence & 1.745 & 16.3 & 0.9577 \\
\hline
\end{tabular}

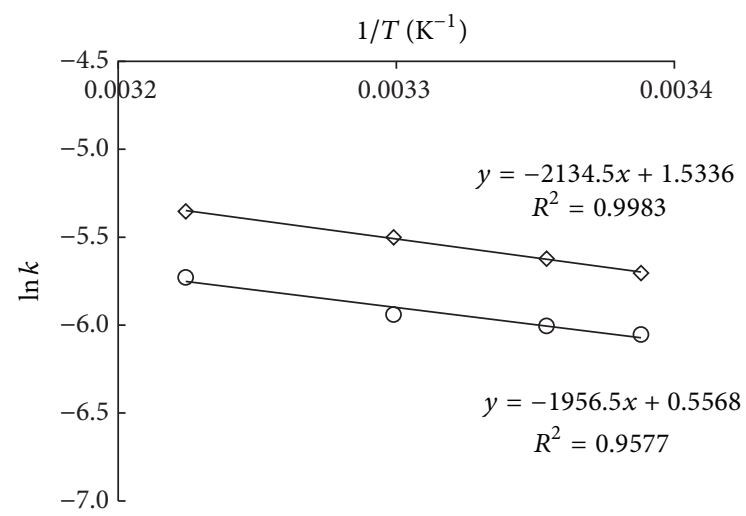

FIGURE 4: Effect of temperature on HRP activity and determination of activation energy $E_{a}:(\diamond)$ in the absence of inhibitor and $(O)$ in the presence of $2 \mathrm{mM}$ of $\mathrm{K}_{2}\left[\mathrm{~B}_{3} \mathrm{O}_{3} \mathrm{~F}_{4} \mathrm{OH}\right]$. Temperatures were 22, 25, 30 , and up to $37^{\circ} \mathrm{C}$; [Guaiacol] $=1.33 \mathrm{mM} ;\left[\mathrm{H}_{2} \mathrm{O}_{2}\right]=0.42 \mathrm{mM} ; \mathrm{pH}=$ 6.

(Figure 4). The Arrhenius constant $A$ and activation energy $E_{a}$ parameters were obtained from the Arrhenius equations [31]:

$$
\begin{gathered}
k=A e^{-E_{a} / R T}, \\
\ln k=\ln A-\frac{E_{a}}{R \cdot T},
\end{gathered}
$$

where $k$ is the rate constant at corresponding absolute temperature $T, A$ is preexponential "frequency" factor the called Arrhenius constant, $E_{a}$ is the activation energy $\left(\mathrm{kJ} \mathrm{mol}^{-1}\right)$, and $R$ is the universal gas constant $(\mathrm{J} / \mathrm{mol})$.

In our study activation energy $E_{a}$ values were found to be very similar for both reactions $\left(17.7 \mathrm{~kJ} \mathrm{~mol}^{-1}\right.$ in the absence and $16.3 \mathrm{~kJ} \mathrm{~mol}^{-1}$ in the presence of inhibitor), but the values of Arrhenius constants $A$ were found to be significantly different, 4.635 and 1.745, respectively, Table 1.

In enzyme reaction, the relative orientation of enzyme at the point of collision with substrate is important. In general the Arrhenius constant $A$ is expressed as

$$
A=Z \rho,
$$

where $Z$ is "frequency" factor and $\rho$ is a geometrical or steric factor.

Although values of steric factor $\rho$ are difficult to assess in large macromolecules such as enzymes, it can be estimated from observed rate constant with the one in which $A$ is assumed to be the same as $Z$. In our study, in the absence $\mathrm{K}_{2}\left[\mathrm{~B}_{3} \mathrm{O}_{3} \mathrm{~F}_{4} \mathrm{OH}\right]$ it can be assumed that $A$ is the same as $Z$ and in the presence of $\mathrm{K}_{2}\left[\mathrm{~B}_{3} \mathrm{O}_{3} \mathrm{~F}_{4} \mathrm{OH}\right]$ the observed different

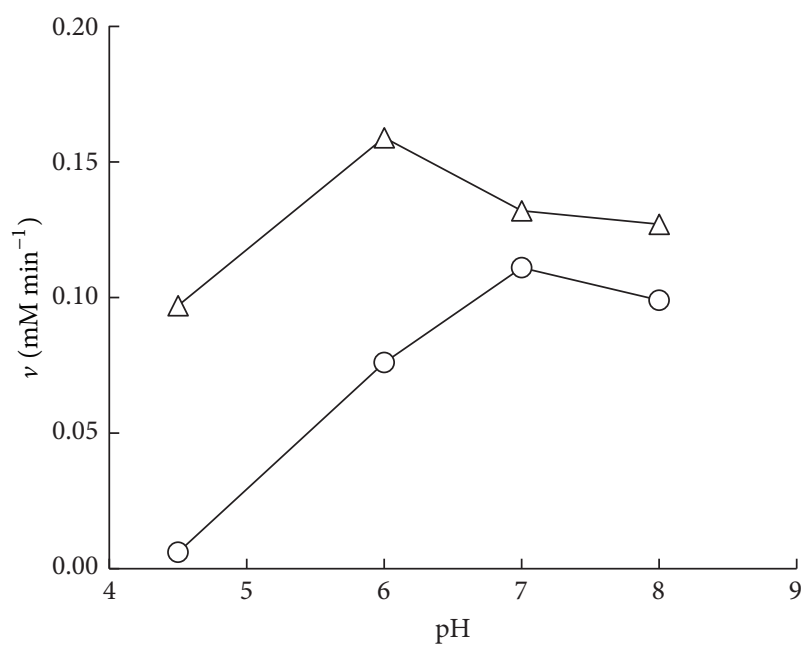

Figure 5: Effect of $\mathrm{pH}$ on HRP activity: $(\triangle)$ in the absence of inhibitor and $(\mathrm{O})$ in the presence of $2 \mathrm{mM}$ of $\mathrm{K}_{2}\left[\mathrm{~B}_{3} \mathrm{O}_{3} \mathrm{~F}_{4} \mathrm{OH}\right]$ at fixed concentrations of [Guaiacol] $=1.33 \mathrm{mM}$ and $\left[\mathrm{H}_{2} \mathrm{O}_{2}\right]=0.42 \mathrm{mM} ; t=$ $22^{\circ} \mathrm{C}$.

value of rate constant could be due to change of steric factor. This allows us to conclude that $\mathrm{K}_{2}\left[\mathrm{~B}_{3} \mathrm{O}_{3} \mathrm{~F}_{4} \mathrm{OH}\right]$ induces a conformational change in HRP molecule affecting steric factor $\rho$ and thus reduces both HRP activity and the rate of reaction, without change of the value of activation energy $E_{a}$.

3.4. Effect of $p H$ on HRP Activity. From the performed $\mathrm{pH}$ assay, it appears that, in the absence of inhibitor, the HRP operates the best at conditions around $\mathrm{pH}=6$ and in the presence of $\mathrm{K}_{2}\left[\mathrm{~B}_{3} \mathrm{O}_{3} \mathrm{~F}_{4} \mathrm{OH}\right]$ the optimum value is around $\mathrm{pH}=$ 7 (Figure 5). It shows that the presence of $\mathrm{K}_{2}\left[\mathrm{~B}_{3} \mathrm{O}_{3} \mathrm{~F}_{4} \mathrm{OH}\right]$ affects HRP activity by altering the state of ionization of the amino acids in the active sites of the enzyme.

3.5. Possible Biologic Activity of $\mathrm{K}_{2}\left[\mathrm{~B}_{3} \mathrm{O}_{3} \mathrm{~F}_{4} \mathrm{OH}\right]$. As reactive oxygen species (ROS), $\mathrm{H}_{2} \mathrm{O}_{2}$ is shown to be toxic but also functions as signalling molecule in cell [32]. Resistance of tumour cells against intercellular signalling depends on interference through peroxidase and catalase expression on the cell membrane. Intercellular ROS signalling of tumour cells can be restored when $\mathrm{H}_{2} \mathrm{O}_{2}$ is supplied and antioxidant enzymes peroxidase and catalase are inhibited. These findings define the biochemical basis for specific apoptosis induction in tumour cells and it represents a potential novel approach in tumour prevention and therapy [33]. In one study [34] it was showed that malignant lung tumours have significantly decreased antioxidant enzymes activity and authors suggested that it could play a possible role in cancer etiology. In one other study [35] it was suggested that antioxidant enzymes may have multifactorial effects in malignant cells and may decrease tumour progression by modulating the cellular redox state, but enhanced antioxidant capacity of mesothelioma cells also may protect tumour cells against exogenous oxidants. Besides it was shown that loss of catalase activity is associated with increased susceptibility to oxidative stress [36-38]. In previous study [11] it was hypothesized that 
local application of $\mathrm{K}_{2}\left[\mathrm{~B}_{3} \mathrm{O}_{3} \mathrm{~F}_{4} \mathrm{OH}\right]$ containing cream or by its intratumour injection of millimolar concentrations could significantly reduce catalase activity and increase the concentration of $\mathrm{H}_{2} \mathrm{O}_{2}$ and accordingly produce beneficial effects in tumour tissue alone. In the wake of these considerations, the study of interactions of $\mathrm{K}_{2}\left[\mathrm{~B}_{3} \mathrm{O}_{3} \mathrm{~F}_{4} \mathrm{OH}\right]$ with HRP and $\mathrm{H}_{2} \mathrm{O}_{2}$ is a contribution to the understanding of its previously observed antitumour activity.

\section{Conclusion}

The $\mathrm{K}_{2}\left[\mathrm{~B}_{3} \mathrm{O}_{3} \mathrm{~F}_{4} \mathrm{OH}\right]$ as inhibitor binds to both the native HRP enzyme and Compound II with equal affinity. The $\mathrm{HRP} /$ inhibitor complex is completely inactive and does not react with $\mathrm{H}_{2} \mathrm{O}_{2}$ while the Compound II/inhibitor complex is fully active with respect to Guaiacol oxidation. In relation to hydrogen peroxide kinetic measurements, $\mathrm{K}_{2}\left[\mathrm{~B}_{3} \mathrm{O}_{3} \mathrm{~F}_{4} \mathrm{OH}\right]$ has no effect on the maximum velocity and increases $K_{m}$ in a linear fashion with inhibitor concentration showing an example of pure competitive inhibition. The activation energy $E_{a}$ has very similar value in the absence and in the presence of inhibitor, suggesting that inhibitor $\mathrm{K}_{2}\left[\mathrm{~B}_{3} \mathrm{O}_{3} \mathrm{~F}_{4} \mathrm{OH}\right]$ induces a conformational change in HRP molecule which affects the steric factor $\rho$ and reduces Arrhenius constant $A$ and thus reduces both HRP activity and the rate of catalytic reaction, without change of the value of activation energy $E_{a}$. It has been shown that $\mathrm{pH}$ affects inhibitors properties of $\mathrm{K}_{2}\left[\mathrm{~B}_{3} \mathrm{O}_{3} \mathrm{~F}_{4} \mathrm{OH}\right]$. An optimal effect on HRP activity was around $\mathrm{pH}=6$ in the absence and $\mathrm{pH}=7$ in the presence of $\mathrm{K}_{2}\left[\mathrm{~B}_{3} \mathrm{O}_{3} \mathrm{~F}_{4} \mathrm{OH}\right]$.

\section{Conflicts of Interest}

The authors declare that there are no conflicts of interest regarding the publication of this paper.

\section{Acknowledgments}

This work has been fully supported by Croatian Science Foundation under Project no. HRZZ-IP-2014-09-6897.

\section{References}

[1] D. G. Hall, Boronic Acids, John Wiley and Sons, New York, NY, USA, 2005.

[2] W. A. Marinaro, L. J. Schieber, E. J. Munson, V. W. Day, and V. J. Stella, "Properties of a model aryl boronic acid and its boroxine," Journal of Pharmaceutical Sciences, vol.101, no. 9, pp. 3190-3198, 2012.

[3] B. Galic, "Boroxine composition for removal of skin changes," US Patent US8278289, 2012.

[4] B. Galic, "Removal of skin changes," European Patent EP1996514, 2013.

[5] S. Haveric, A. Haveric, K. Bajrovic, B. Galic, and M. Maksimovic, "Effects of dipotassium trioxohydroxytetrafluorotriborate $\left(\mathrm{K}_{2}\left[\mathrm{~B}_{3} \mathrm{O}_{3} \mathrm{~F}_{4} \mathrm{OH}\right]\right)$ on genetic material and inhibition of cell division in human cell cultures," Drug and Chemical Toxicology, vol. 34, no. 3, pp. 250-254, 2011.
[6] M. Hadžić, S. Haverić, A. Haverić, and B. Galić, "Inhibitory effects of delphinidin and luteolin on genotoxicity induced by $\mathrm{K}_{2}\left(\mathrm{~B}_{3} \mathrm{O}_{3} \mathrm{~F}_{4} \mathrm{OH}\right)$ in human lymphocytes in vitro," Biologia, vol. 70, no. 4, pp. 553-558, 2015.

[7] S. Ivankovic, R. Stojkovic, Z. Galic et al., "In vitro and in vivo antitumor activity of the halogenated boroxine dipotassiumtrioxohydroxytetrafluorotriborate $\left(\mathrm{K}_{2}\left[\mathrm{~B}_{3} \mathrm{O}_{3} \mathrm{~F}_{4} \mathrm{OH}\right]\right)$," Journal of Enzyme Inhibition and Medicinal Chemistry, vol. 30, no. 3, pp. 354-359, 2015.

[8] D. Vullo, E. Ruusuvuori, K. Kaila, A. Scozzafava, and C. T. Supuran, "Carbonic anhydrase inhibitors: inhibition of the cytosolic human isozyme VII with anions," Bioorganic and Medicinal Chemistry Letters, vol. 16, no. 12, pp. 3139-3143, 2006.

[9] G. De Simone and C. T. Supuran, "(In)organic anions as carbonic anhydrase inhibitors," Journal of Inorganic Biochemistry, vol. 111, pp. 117-129, 2012.

[10] J.-Y. Winum, A. Innocenti, A. Scozzafava, J.-L. Montero, and C. T. Supuran, "Carbonic anhydrase inhibitors. Inhibition of the human cytosolic isoforms I and II and transmembrane, tumorassociated isoforms IX and XII with boronic acids," Bioorganic \& Medicinal Chemistry, vol. 17, no. 10, pp. 3649-3652, 2009.

[11] S. Islamovic, B. Galic, and M. Milos, "A study of the inhibition of catalase by dipotassium-trioxohydroxytetrafluorotriborate, $\mathrm{K}_{2}\left[\mathrm{~B}_{3} \mathrm{O}_{3} \mathrm{~F}_{4} \mathrm{OH}\right]$," Journal of Enzyme Inhibition and Medicinal Chemistry, vol. 29, no. 5, pp. 744-748, 2014.

[12] D. Vullo, M. Milos, B. Galic, A. Scozzafava, and C. T. Supuran, "Dipotassium-trioxohydroxytetrafluorotriborate, $\mathrm{K}^{2}\left[\mathrm{~B}^{3} \mathrm{O}^{3} \mathrm{~F}^{4} \mathrm{OH}\right]$, is a potent inhibitor of human carbonic anhydrases," Journal of Enzyme Inhibition and Medicinal Chemistry, vol. 30, no. 2, pp. 341-344, 2015.

[13] M. Zamocky, P. G. Furtmüller, and C. Obinger, "Evolution of catalases from bacteria to humans," Antioxidants and Redox Signaling, vol. 10, no. 9, pp. 1527-1548, 2008.

[14] A. Henriksen, D. J. Schuller, K. Meno, K. G. Welinder, A. T. Smith, and M. Gajhede, "Structural interactions between horseradish peroxidase $\mathrm{C}$ and the substrate benzhydroxamic acid determined by X-ray crystallography," Biochemistry, vol. 37, no. 22, pp. 8054-8060, 1998.

[15] R. Chatterjee, U. Bandyopadhyay, D. Bhattacharyya, and R. K. Banerjee, "Inhibition of intestinal peroxidase activity by nonsteroidal antiinflammatory drugs," Biochimica et Biophysica Acta (BBA)/Protein Structure and Molecular, vol. 1161, no. 2-3, pp. 168-176, 1993.

[16] H. B. Dunford, "Horseradish peroxidase: structure and kinetic properties," in Peroxidases in Chemistry and Biology, J. Everse, K. R. Everse, and M. B. Grisham, Eds., vol. 2, pp. 1-24, CRC Press, Boca Raton, Fla, USA, 1991.

[17] N. C. Veitch, "Horseradish peroxidase: a modern view of a classic enzyme," Phytochemistry, vol. 65, no. 3, pp. 249-259, 2004.

[18] G. Bonifert, L. Folkes, C. Gmeiner, G. Dachs, and O. Spadiut, "Recombinant horseradish peroxidase variants for targeted cancer treatment," Cancer Medicine, vol. 5, no. 6, pp. 1194-1203, 2016.

[19] I. G. Ryss and M. M. Slutskaya, "Report on the platinum sector," Academy of Sciences of USSR, vol. 26, pp. 216-218, 1951.

[20] B. Chance and A. C. Maehly, "[136] Assay of catalases and peroxidases," Methods in Enzymology, vol. 2, pp. 764-775, 1955.

[21] M. Santimone, "Titration study of guiacol oxidation by horseradish peroxidase," Canadian Journal of Biochemistry, vol. 53, no. 6, pp. 649-657, 1975. 
[22] M. Marasović, T. Marasović, and M. Milos, "Robust nonlinear regression in enzyme kinetic parameters estimation," Journal of Chemistry, In press.

[23] A. G. Splittgerber, "Simplified treatment of two-substrate enzyme kinetics," Journal of Chemical Education, vol. 60, no. 8, pp. 651-655, 1983.

[24] A. G. Marangoni, “Two substrate reactions," in Enzyme Kinetics: A Modern Approach, pp. 90-101, John Wiley \& Sons, Inc, New York, NY, USA, 2003.

[25] K. A. Johnson and R. S. Goody, "The original Michaelis constant: translation of the 1913 Michaelis-Menten Paper," Biochemistry, vol. 50, no. 39, pp. 8264-8269, 2011.

[26] H. Lineweaver and D. Burk, "The determination of enzyme dissociation constants," Journal of the American Chemical Society, vol. 56, no. 3, pp. 658-666, 1934.

[27] P. Ascenzi, M. G. Ascenzi, and G. Amiconi, "Enzyme competitive inhibition, graphical determination of $\mathrm{K}_{i}$ and presentation of data in comparative studies," Biochemical Education, vol. 15, no. 3, pp. 134-135, 1987.

[28] P. Vanachayangkul and W. H. Tolleson, "Inhibition of heme peroxidases by melamine," Enzyme Research, vol. 2012, Article ID 416062, 7 pages, 2012.

[29] R. Chatterjee, U. Bandyopadhyay, D. Bhattacharyya, and R. K. Banerjee, "Inhibition of intestinal peroxidase activity by nonsteroidal antiinflammatory drugs," Biochimica et Biophysica Acta (BBA)_Protein Structure and Molecular Enzymology, vol. 1161, no. 2-3, pp. 168-176, 1993.

[30] A. M. L. Zatón and E. Ochoa de Aspuru, "Horseradish peroxidase inhibition by thiouracils," FEBS Letters, vol. 374, no. 2, pp. 192-194, 1995.

[31] K. J. Laidler, "The development of the arrhenius equation," Journal of Chemical Education, vol. 61, no. 6, pp. 494-498, 1984.

[32] B. D'Autréaux and M. B. Toledano, "ROS as signalling molecules: mechanisms that generate specificity in ROS homeostasis," Nature Reviews Molecular Cell Biology, vol. 8, no. 10, pp. 813-824, 2007.

[33] M. D. Maines, "The heme oxygenase system: a regulator of second messenger gases," Annual Review of Pharmacology and Toxicology, vol. 37, pp. 517-554, 1997.

[34] R. N. Korotkina, G. N. Matskevich, A. S. Devlikanova, A. A. Vishnevskii, A. G. Kunitsyn, and A. A. Karelin, "Activity of glutathione-metabolizing and antioxidant enzymes in malignant and benign tumors of human lungs," Bulletin of Experimental Biology and Medicine, vol. 133, no. 6, pp. 606-608, 2002.

[35] K. Kahlos, Y. Soini, R. Sormunen et al., "Expression and prognostic significance of catalase in malignant mesothelioma," Cancer, vol. 91, no. 7, pp. 1349-1357, 2001.

[36] G. Falkson and M. E. De Jager, "Catalase activity in the epidermis of patients with advanced cancer [38]," Nature, vol. 202, no. 4928, pp. 203-204, 1964.

[37] L. Góth, P. Rass, and A. Páy, "Catalase enzyme mutations and their association with diseases," Molecular Diagnosis, vol. 8, no. 3, pp. 141-149, 2004.

[38] Y.-S. Ho, Y. Xiong, W. Ma, A. Spector, and D. S. Ho, "Mice lacking catalase develop normally but show differential sensitivity to oxidant tissue injury," Journal of Biological Chemistry, vol. 279, no. 31, pp. 32804-32812, 2004. 

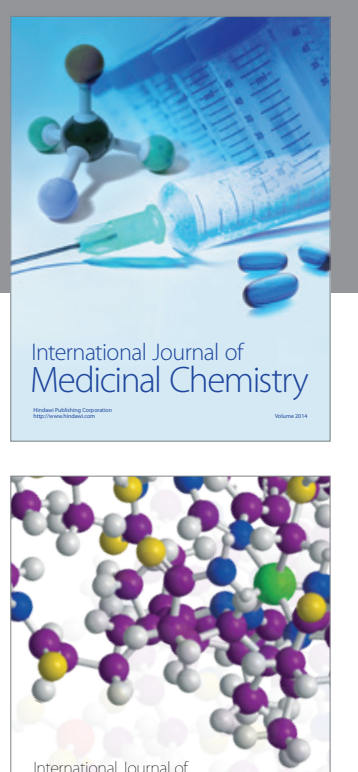

Carbohydrate Chemistry

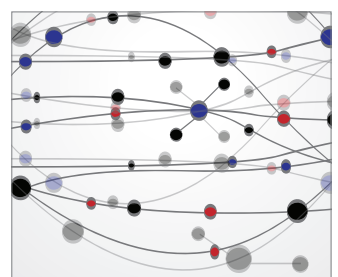

The Scientific World Journal
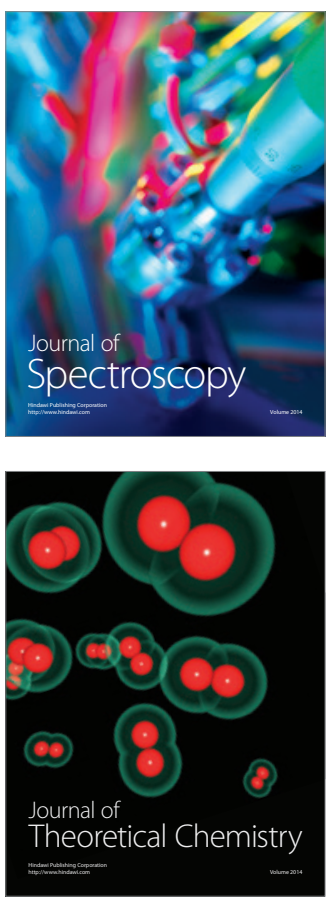
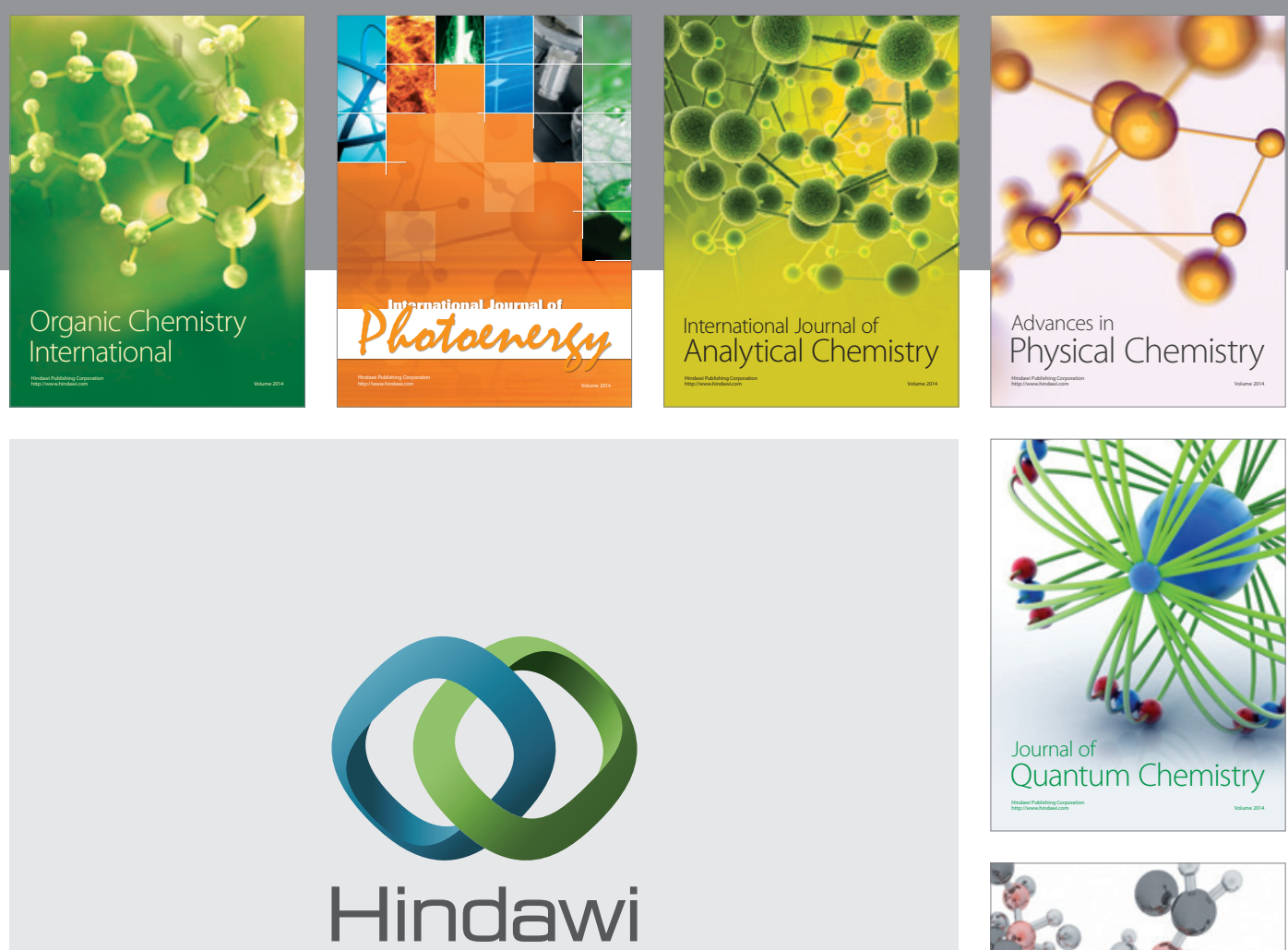

Submit your manuscripts at

https://www.hindawi.com

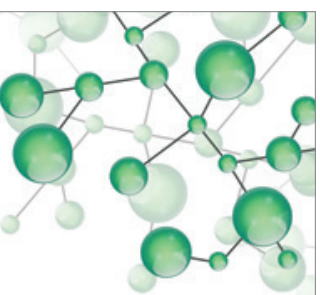

International Journal of

Inorganic Chemistry
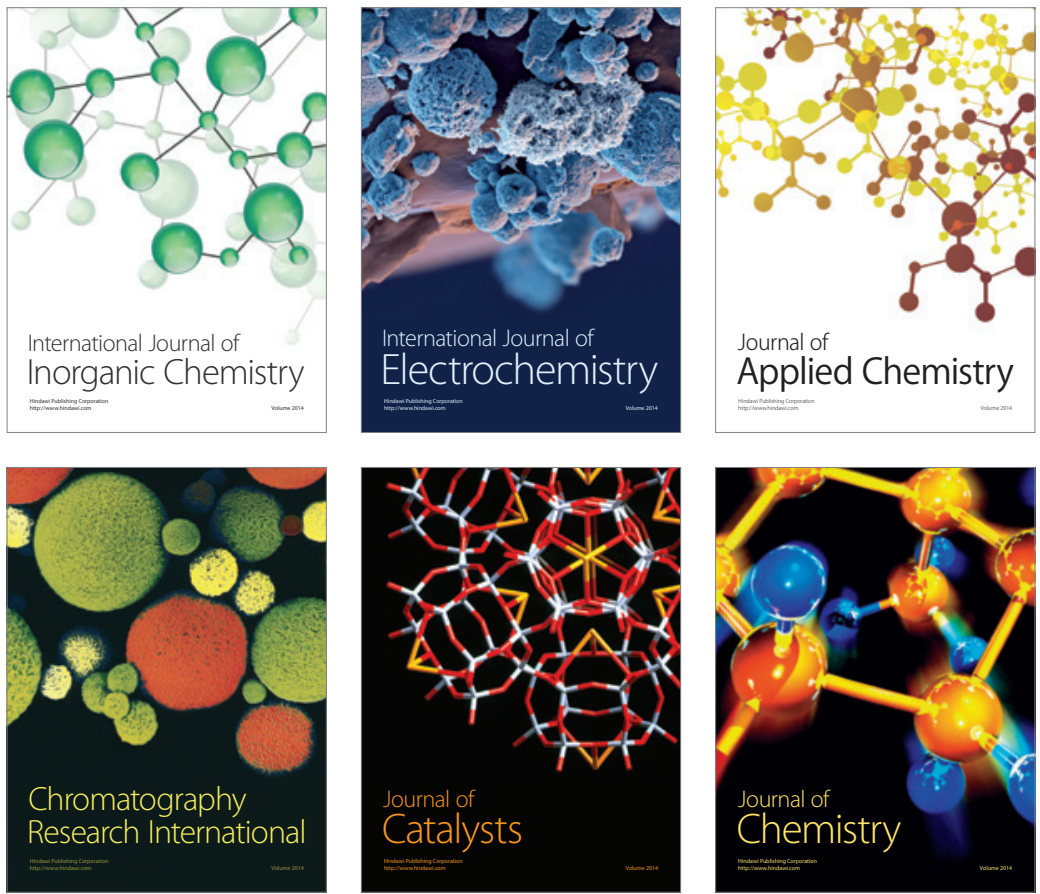

Journal of

Applied Chemistry
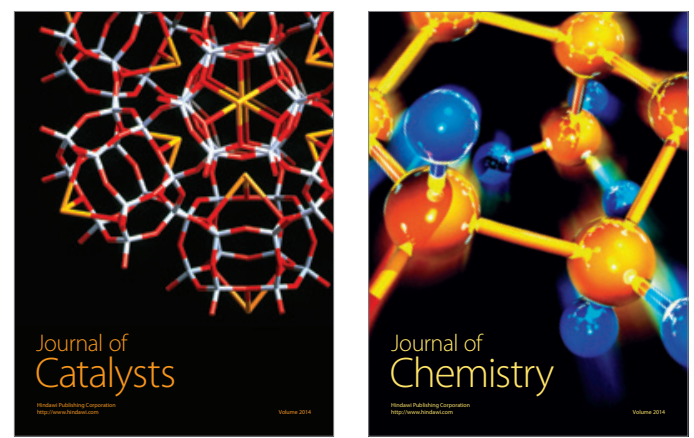
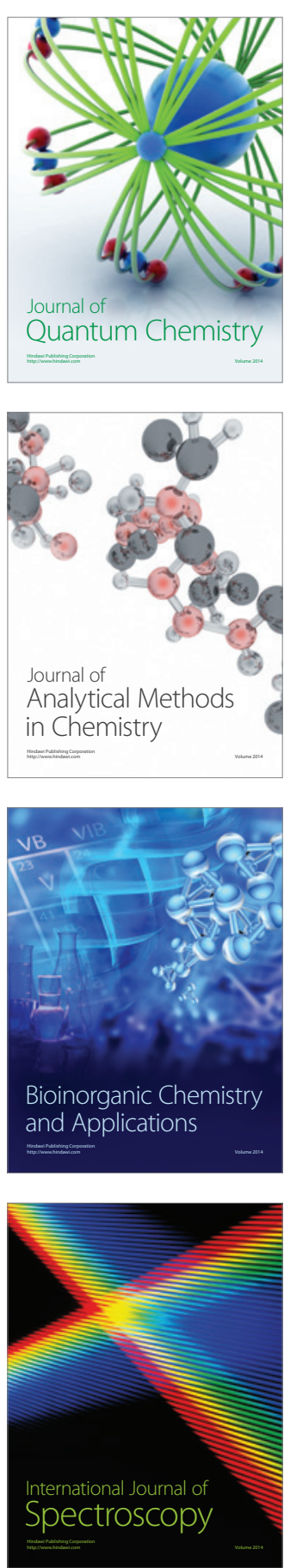